\title{
Título da página electrónica: The Modernist
} Journals Project

Endereço: http://www.modjourn.brown.edu/

\section{António Sousa Ribeiro}

\section{(Q) OpenEdition}

\section{Journals}

Edição electrónica

URL: http://journals.openedition.org/rccs/947

DOI: $10.4000 /$ rccs.947

ISSN: 2182-7435

\section{Editora}

Centro de Estudos Sociais da Universidade de Coimbra

Edição impressa

Data de publição: 1 junho 2006

Paginação: 151

ISSN: 0254-1106

\section{Refêrencia eletrónica}

António Sousa Ribeiro, «Título da página electrónica: The Modernist Journals Project », Revista Crítica de Ciências Sociais [Online], 74 | 2006, posto online no dia 01 outubro 2012, consultado o 22 setembro 2020. URL : http://journals.openedition.org/rccs/947 ; DOI : https://doi.org/10.4000/rccs.947 


\section{Espaço Virtual}

\section{Título da página electrónica: Modernist Studies Association Endereço: http://msa.press.jhu.edu/}

A fundação da MSA, em 1998, com a intenção de constituir um fórum aberto à dinâmica interdisciplinar contemporânea, testemunha a crescente vitalidade dos estudos sobre o modernismo. A Associação prossegue o objectivo programático do estudo das artes nos seus contextos sociais, políticos, culturais e intelectuais desde o final do século XIX. Entre outras actividades, organiza uma conferência anual. A $8 .^{a}$ conferência irá realizar-se em Tulsa, EUA, entre 19 e 22 de Outubro de 2006. O tema geral, "Out of the Archive", visa investigar os modos como o recurso a arquivos dos mais diferentes tipos - visuais, literários, cinematográficos, jornalísticos, pessoais, musicais - influencia a estrutura e os limites do modernismo. Uma mesa redonda intitulada "Displaced Modernisms" ocupa um lugar central no programa do congresso. A MSA publica a revista trimestral Modernism/Modernity, que constitui no momento presente a mais relevante publicação periódica no âmbito dos estudos modernistas. A página da MSA oferece uma área de acesso reservado aos membros da Associação, em que está, nomeadamente, disponível a consulta da versão online de Modernism/Modernity. A área de acesso livre, bem organizada e de fácil navegação, oferece informação sumária sobre as actividades e iniciativas da MSA.

\section{Título da página electrónica: The Modernist Journals Project Endereço: http://www.modjourn.brown.edu/}

Sediado nas Universidades de Brown e de Tulsa, este projecto visa proporcionar o acesso digital a publicações periódicas do modernismo anglo-saxónico, incluindo os chamados "little magazines". O núcleo inicial do projecto, o acesso digital à revista The New Age (1907-1922), irá sendo alargado a um conjunto de outras publicações, que inclui, para já, Dana (1904-1905), anunciando-se para breve a disponibilização da publicação vorticista Blast, dirigida por Wyndham Lewis. O projecto inclui também publicações do âmbito dos estudos modernistas, estando já disponível a importante revista de estudos fílmicos Ciné-Tracts (1977-1982) e prevendo-se a colocação online proximamente dos números atrasados de The James Joyce
Quarterly, desde a fundação da revista em 1964. O texto das revistas em PDF surge enquadrado por um conjunto de introduções, glossários e estudos críticos. Estão também disponíveis versões integrais de alguns livros, incluindo The Sanity of Art: An Exposure of the Current Nonsense about Artists being Degenerate (1908), de George Bernard Shaw. Uma secção de ensaios, ainda embrionária, destina-se a acolher estudos recentes sobre textos modernistas.

O acervo disponível nesta página não é ainda muito extenso, mas constitui já um recurso valioso, que se irá tornando crescentemente relevante à medida que novos títulos vão sendo incluídos. A navegação é intuitiva e o acesso fácil e rápido. 


\section{Título da página electrónica: Long Term Research Project (SFB) “Modernity: Vienna and Central Europe around 1900" \\ Endereço: http://www-gewi.kfunigraz.ac.at/moderne/edok.htm}

Trata-se da versão inglesa (menos actualizada do que a versão alemã, disponível em http://www-gewi.kfunigraz.ac.at/ moderne/dok.htm) da página do projecto "Moderne. Wien und Zentraleuropa um 1900”. Sediado na Universidade de Graz, este projecto, realizado entre 1994 e 2004 , levou a cabo um ambicioso programa de investigação transdisciplinar centrado no contexto modernista austríaco e da Europa Central e assente num amplo re-exame crítico dos conceitos de modernismo e modernidade tal como se apresentam nesse contexto. O projecto desdobrou-se em cinco grupos de investigação transdisciplinares: "Ismos e ideologias"; "Estética da modernidade - estética modernista"; "Cultura e sociedade"; "Transferências culturais"; "Identidades". A página é muito rica em informação (uma parte dela em alemão) quanto aos resultados do projecto e às inúmeras conferências e publicações dele resultantes. Permite também o acesso aos números da "Newsletter Moderne", publicada regularmente no âmbito do projecto.

Com o intuito de prosseguir os objectivos do projecto para além do seu termo, o corpo de investigadores fundou entretanto uma associação, a "Forschungsgesellschaft Moderne/Postmoderne”, sediada igualmente na Universidade de Graz (http:// www-gewi.uni-graz.at/fomop/home.html).

António Sousa Ribeiro

asr@mail.net4b.pt 